Dokuz. Eylül Üniversitesi

İlahiyat Fakeültesi Dergisi

2015/1, Sayn 41, ss. 243-270.

\title{
MODERN SOSYOLOJİDE İŞLEVSELCİLİK - EYLEMCİLİK TEORİLERİ İKİLİĞİNİ AŞMA ÇABALARI
}

\author{
İsa KUYUCUOĞLU*
}

\section{ÖZET}

Toplumu oluşturan her unsurun özel bir işlevinin olduğunu ve bunların karşılıklı olarak birbirlerini etkilediğini kabul eden "işlevselcilik" ile insanın eylemde bulunan bir edimci olduğu görüşüyle bireye etkin bir rol yükleyen "eylemcilik teorileri” arasındaki ikilik, daha doğrusu "karşıtlık" çağdaş sosyolojide ciddi bir sorun olarak görülmektedir. Sosyolojik teorilerin, "işlevselcilik" ve "eylemselcilik" olarak iki temel paradigmaya ayrılması yapı-aktör, nesnelcilik-öznelcilik, yöntemsel bütüncülük-yöntemsel bireycilik karşıtlıklarını ortaya çıkarmaktadır.

Modern sosyolojideki teorik yaklaşımlarda klasik sosyolojideki ikiliklerin aşılması yönündeki çalıșmalar önem kazanmaktadır. Bu nedenle bu makalede Pierre Bourdieu (1930-2002), Jürgen Habermas (1929-) ve Anthony Giddens (1938-)'in “işlevselcilik (functionalism) teorisi" ile "eylem (action)" teorisi arasındaki ikilemi aşmak üzere geliştirdikleri yeni yaklaşımları ve buna bağlı olarak James S. Coleman (1926-1995)'ın "akılcı seçim teorisi" (rational choice theory) analiz edilmektedir.

Ayrıca çă̆daş sosyologların klasik sosyolojinin temel paradigmalarının modern toplumun karmaşık yapısının analizinde yetersiz kaldığını varsayarak, "mikro ve makro" düzeylerdeki toplumsal süreçlerin "aktör" ve "yapı" bireşimi içinde çağdaş kavram ve kuramlarla yeniden ele alınması gerektiği konusundaki düşünceleri incelenmeye çalışılmıştır.

Anahtar sözcükler: Eylem teorisi, işlevselcilik, akılc1 seçim teorisi.

\section{THE EFFORTS OF OVERCOMING THE DICATHOMY BETWEEN FUNCTIONALIST AND ACTION THEORIES IN MODERN SOCIOLOGY}

\section{ABSTRACT}

In contemporary sociology, the "dualism" or, in other words "a contrast" is regarded a serious issue between "functionalism" which views that every element forming the society has a specific function and each of them has a mutual function on one another, and "action theory" which gives an active role to individual. Sociological theories which are divided as "functionalism" and "action theory" have brought about other dualities such as "structure" vs. "actor", "subjectivism" vs. "objectivism, "methodological holism" vs. "methodological individualism".

Yrd. Doç. Dr., Dokuz Eylül Üniversitesi, İlahiyat Fakültesi, Din Sosyolojisi ABD Öğretim Üyesi 
In modern sociology, research on overcoming the dichotomy of classical sociology in new theoretical approaches stand out in contemporary sociology. For this reason, in this article I will analyze Pierre Bourdieu (1930-2002), Jürgen Habermas (1929-) and Anthony Giddens (1938-) with their new approaches which aim to overcome the duality between functionalism and action theory and consequently James S. Coleman's "rational choice theory".

Furthermore I will discuss the assumptions of modern sociologists that the fundamental paradigms of the classical sociology is not enough for analysing the complex structure of modern society and hence the social process on "micro-macro" levels must be refocused on the modern concepts and theories of actor vs. structure.

Key words: Social action theory, functionalism, rational action theory.

\section{GİRİŞ}

Varlıklar içinde sadece insan düşünen, düşüncelerine uygun eylemler yapan ve çevresiyle sosyal etkileşim içinde kendi dünyasını kurma yeteneğine sahip olan bir varlıktır. Kendi doğası ve gereksinimlerine uygun bir dünya kuracak irade ve özgürlüğe sahip olan insanın evreni boş ve anlamsız değildir. Beşeri eylemlerle oluşturulan sosyal çevre insan hayatının temelini oluşturur. Kendisinden önce kurulmuş bir sosyal çevrede dünyaya gözlerini açan insanın toplumsal hayattaki geçmişi gelecekte meydana gelecek davranışların sınırlarını belirler.

İnsan eylemlerini konu edinen eylem teorisi (social action theory)" ile klasik sosyolojideki ișlevselcilik (functionalism) teorisi arasındaki ikilik günümüz sosyolojisinin önemli konularından biri haline gelmiştir. ${ }^{1}$ Modern sosyolojide önemli bir paradigma haline gelen "eylem teorisi" sadece aksiyonun doğal yapısını değil, onun anlam ve yorumunu ve aktör-yap1 ilişkilerinde aktörün rolünü de araştırma konusu yapmaktadır.

İşlevselcilik teorisi açısından toplum bireylerin toplamından ve bireysel eylemlerden daha kapsamlı bir sistem olarak kabul edilmesine karşın, ${ }^{2}$ toplumsal eylem teorisi bireyi ve onun eylemlerini konu edinmektedir. ${ }^{3}$

Sosyal bilimlerin araştırma konuları ve yöntem açısından sistem ile eylem veya yapı ile aktör arasında günümüz sosyolojisinde yaşanan bu ikilik nedeniyle sosyolog Alan Dawe, "tek tip sosyoloji yoktur; sosyal sistemler sosyolojisi ve toplumsal eylemler sosyolojisi olmak üzere iki tip sosyoloji vardır"

1 Margareta Bertilsson, "Fra Aristoteles til Moderne Samfundsteori", Klassisk og Moderne Samfundsteori (Ed. Heinne Andersen og Lars Bo Kaspersen), Hans Reitzels Forlag, Kopenhag 2011. ss. 629-630.

2 Steen Nepper Larsen og Inge Kryger Pedersen, Sociologisk Leksikon, Kopenhag 2011, ss.224.

3 Lars Bo Kaspersen og Anders Blok, "Teorisynteser og Nybrud i Moderne Sociologi", Sociologi: En grundbog til fag, Hans Reitzel Forlag, Kopenhag, 2011, s. 75. 
demektedir. ${ }^{4}$ Onun bu ifadeleri toplumsal yapıya odaklanan "işlevselcilik" ile toplumsal aktörlerin iradi ve bilinçli fillerine yönelen "eylemselcilik" arasındaki farkı bariz bir şekilde ortaya koymaktadır.

İşlevselcilik teorisinin sosyolojide uzun bir dönem sağladığ hâkimiyetin, 2. Dünya savaşından ve özelikle 1960'lardan sonra kaybolmasindan sonra günümüz sosyolojisinde Yeni Webercilik'ten Yeni Parsonizm'e ve Yapısalculık'dan Postmodernizm'e kadar uzanan bir ayrışma yaşanmaktadır. ${ }^{5}$ Bir kısım çağdaş sosyoloji kuramciları eylem teorisi hakkında yaptıkları analizlerle bu ayrışmayı gidermeye çalışmaktadırlar.

\section{EYLEM TEORİSI}

Eylem teorisi toplumsal koşulların beşeri fiiller açısından ele alındığı sosyolojik bir yaklaşımı ifade eder. ${ }^{6} \mathrm{Bu}$ teoriyle alakalı farklı yaklaşımların ortak paydası toplumsal aktörlerin eylemlerinin merkezde düşünülmesi, yani bireyci perspektifin öne çıkmasıdır.

Sadece eylemin doğasıyla değil anlam ve yorumuyla da ilgilenen eylem teorisi açısından farklı bağlamlarda yapılan eylemlerin eyleyen için taşıdığı anlam önemlidir.7 Sosyal dünyayı inşa eden veya değiştiren birey veya grupların (aktörlerin) eylemlerinin toplumun temelini oluşturduğunu varsayan bu teori aktörlerin istemli veya istemsiz fillerinin sosyal kurumları ve toplumsal yapılar1 oluşturduğunu kabul eder. ${ }^{8}$

Eylem teorisi felsefi olarak her ne kadar Aristo'ya dayandırlsa da sosyolojik olarak genellikle Max Weber tarafindan kurulduğu kabul edilmektedir. ${ }^{9}$ Eylem kavramını soyut terimlerle açıklamakla yetinmeyen Weber eylemin boyut ve içeriğini ampirik araştırmalarla netleştirmiştir. Weber'den sonra Talcott Parsons "istençli (voluntary) eylem teorisi" hakkında yaptığı çalışmalarla teorinin muhtevasını genişletmiş̧ir. ${ }^{10}$ Günümüzde ise eylem teorisi içinde değerlendirilen akulsal seçim teorisi (rational choice theory) veya akılsal eylem teorisi (rational action theory) bireysel norm ve değerlere odaklanmaktadır. Belli

4 Kaspersen og Blok, a.g.e., s. 76.

4. Kaspersen og Blok a.g.e., s. 77.

6 Larsen og Pedersen, a.g.e, ss. 224-225.

7 Marshall, Gordon, Sosyoloji Sö̊lügü, çev. Osman Akınbay ve Derya Kömürcü, Bilim ve Sanat Yayınları, Ankara 1999, s. 227.

8 Jens Peter Thomsen F., "Diskursanalyse", Klassiske og Moderne Samfundsteori (Ed. Heine Andersen og Lars Bo Kaspersen), Hans Reitzels Forlag, Kopenhag 2011, s. 189.

9 Daha geniş bilgi için bkz. Alan Dawe, "The Two Sociologies”, British Journal of Sociology, 1970, vol. 21: 2 s. 16-18.

10 Talcott Parsons, The Structure of Social Action, Free Press, 1937 London. 
durumlarda yapılan amaçlı eylem eksenli akılsal seçim teorisi aktörün eylemde bulunma özgürlüğünü öne çıkarır. ${ }^{11} \mathrm{Bu}$ yaklaşımda özellikle bireysel akılc1lığa vurgu yapildığ halde, sosyologlar arasında akılcilı̆ga hangi düzeyde önem verileceği konusunda bir görüş birliğine varılmadığı anlaşılmaktadır. ${ }^{12}$

Eylem teorisi hakkındaki yaklaşımlar genel olarak bermeneutik (yorumsamacı) ve pozitivist (olgucu) olmak üzere iki açıdan ele alınmakta ve Hermeneutik eylem teorisi fenomenoloji ve hermeneutik ile pozitivist eylem teorisi ise sistem ve yapr ile ilişkilendirilmektedir. ${ }^{13}$

Hermeneutik eylem teorisi Klasik dönemde Weber'in 'ideal tipik eylem" modelleri hakkında geliştirdiği eylem tipolojisinden sembolik etkileşim, fenomenoloji ve etno-metodolojiye, modern dönemde ise faydac1 eylem teorisinden akılsal seçim teorisine kadar uzanan geniş bir yelpazede ele alınmaktadır. ${ }^{14}$

Eylem teorisi hakkındaki bu girişten sonra eylemcilik ve islevselcilik kuramlarının modern sosyolojideki en önemli temsilcileri olan Fransız Pierre Bourdieu, İngiliz Anthony Giddens, Alman Jürgen Habermas ve Amerikalı James S. Coleman'ın konuya yaklaşımları incelenmeye çalışılacaktır.

\subsection{PIERRE BOURDIEU}

Genellikle ampirik araştırmalara dayandırdı̆̆ kuramlarla tanınan Bourdieu özellikle sosyolog ve antropologlar arasında geniş kabul görmüştür. ${ }^{15}$ Cezayir'de yaptığ1 antropolojik ve sosyolojik araştırmalarla, birbirine zit gibi görünen kavram ve teorileri uzlaştırmaya çalş̧an Bourdieu hem sosyoloji hem de antropoloji alanında özgün yöntemler geliştirmiştir. ${ }^{16}$

11 Larsen og Pedersen, a.g.e, s. 224.

12 Birbirleriyle ilişkili olan "eylem" kavramı ile "davranış” kavramı arasında önemli bir fark vardır. "Davranış", genellikle mekanik, yansımasız ve kasıtsız refleksleri, eylem ise amaçlılık, yorum ve anlamayı ifade eder. Aktör veya aktörler tarafindan gerçekleştirilen eylem aktörün öznel yorum ve anlamlandırmalarını da kapsar (Bkz. Larsen og Pedersen, 2011, a.g.e. s. 225).

13 Dag Österberg, Sociologiske nöglebegreber og deres oprindelse, Norveççe'den çeviren Manni Crone, Akademisk Forlag, Kopenhag, 2005. s. 69.

14 Larsen og Pedersen, a.g.e., s 224.

15 Farklı alanda çalışmalar yapan Bourdieu'nün temel düşünceleri üç önemli eserde toplanır. $L a$ Reproduction: Éléments pour une théorie du système d'enseignement (1970) adlı eseri, eğitim kurumu olarak okulun toplum yapısını nasıl oluşturup ve tekrar ürettiğini, iki yıl sonra yazdığ1 Esquisse d'une théorie de la pratiq (1972) adlı eseri habitus kavramın1, La Distinction. Critique sociale du jugement (1979) adlı eseri ise sosyal faktör olarak estetiğin rolünü konu edinmektedir (Bkz. Wacquant J.D Loïc ve Bourdieu Pierre, Refleksiv sociologi, s. 18).

16 Margretha Jarvinen, "Pierre Bourdieu”, Klassisk og Moderne Samfundsteori, (ed. Heine Andersen ve Lars Bo Kaspersen), Kopenhag 2011, s.350. 
Eylem teorisi hakkında yaptığ araştırmalarda toplumsal gerçekliğin analizinde öznel veya nesnel bilgi formlarının kendi başına yeterli olmadığını vurgulayan Bourdieu nesnelci ve öznelci yaklaşımları birleştirmeye çalışmaktadır. Toplumsal yaşamın nesnel ve öznel boyutlarının birbirleriyle ilişkilerine sıkça vurgu yapması onun mikero-makro ikiliklerine karşı çıkmasına neden olmuş ve bu yüzden aktör ve yapıdan birini ötekine tercih etmenin doğru olmadığını savunmustur. ${ }^{17}$ Bourdieu çalışmalarında hem nesnel/pozitif hem de öznel/hermeneutik yöntemlerden yararlandığ1 halde metin yorumlamalarına değil, toplumsal yaşamda meydana gelen somut olaylara yöneliştir. ${ }^{18}$

Beşer eylemlerini anlamaya yönelik yeni teoriler geliştirmek için hem Cezayir kabileleri hem de Paris'te üniversite öğrencileri arasında ampirik yöntemlerle yaptığı araştırmalarla Bourdeiu Cezayir'deki kabile üyelerinin evlilik pratiğiyle Paris'teki üniversite öğrencilerinin öğrenimlerinin "sembolik" amacının örtüştüğünü ifade etmektedir. ${ }^{19}$ Bu çalışmasıyla o toplumsal yapılar farklı olmasına rağmen aktörlerin eylemlerinin örtüştügünü göstermek istemiștir.

Yaptığ1 çalışmalarda Bourdieu aşkın ve evrensel geçerli büyük teoriler (grand theories) türetmeyi değil, toplumun hem teorik hem de ampirik olarak incelenmesine katk1 yapacak pratik paradigmalarla bireylerin toplumsal yaşamdaki fiillerini anlayıp açıklamayı hedeflemiştir. ${ }^{20}$

Klasik Marxizm ve Batı Marxizm'i “pratik” terimini normatif bir değer olarak kabul eden Bourdieu bu terime toplumsal bir anlam atfetmektedir. Ona göre "pratik", bir kimsenin başka bir kimseyle somut bağlamda bazı şeyler yapıp etmesi yani toplumsal bir eylem içinde olmasıdır. ${ }^{21}$ Sosyal pratiği açıklamak isteyen sosyolojik teoriler açısından "eylem", onu yapan ile gözleyen arasında karşılıklı ilişki içinde meydana gelen bir süreç olarak değerlendirilmektedir.

Çalışmalarının önemli bir bölümünü eğitim ve kültürel faktörlerin toplumsal süreçlere etkisine ayıran Bourdieu farklı sosyolojik teorik kategoriler arasındaki karşıtlıkları aşmak için sermaye, habitus, simf ve alan kavramları üzerinde çözümlemeler yapmıştır. O bu kavramları araştırma süreçleri tamamlanmış veya doğrudan doğruya gerçeğe dönüştürülebilen boyutlar olarak değil, problemlerin

17 Pierre Bourdieu, Toplumbilim Sorunları. çev. Işık Ergüden. İstanbul 1996, s. 48.

18 Donald Broady, Sociologi og Epistemologi - om Pierre Bourdieus Författerskab och den historiska Epistemologin, HLS Förlag, Stokholm 1990, s. 33.

19 Broady, a.g.e., s. 25.

20 Loï J.D. Wacquant och Bourdieu Pierre, Refleksiv sociologi, Kopenhag 1996., ss. 25-28.

21 Jarvinen, a.g.e., 2011 s. 352. 
çözümlenmesinde başvurulan pragmatik enstrümanlar olarak kabul etmektedir.22

Bourdie'nün klasik sosyolojideki kuramsal ikilikleri aşmak için yaptığ1 çalışmalarda kullandığı önemli kavramlarından biri sermaye (capital)'dir. Ona göre gündelik yaşamda para, taşınır veya taşınmazlar gibi maddi imkânları ifade eden sermayenin farklı türleri vardır. ${ }^{23}$ Ona göre gündelik yaşamdaki anlamının dışında farklı anlamları olan "sermaye' toplumsal yaşamda eyleme dönüştürülebildiğimiz her türlü fiziksel enerjidir."”24 Bourdieu, sermaye kavramını ekonomik (para ve maddi kaynaklar), kültürel (eğitim, öğretim ve kültür) ve sosyal sermaye (aktörün toplumsal hayattaki konumu) olarak üç kategoride ele almaktadır. ${ }^{25}$

En etkili sermaye türü olan ekonomik sermaye doğrudan ve anında paraya dönüştürülebilen veya mülkiyet hakkı olarak kurumsallaştırılabilen bir sermayedir. Aktörün sahip olduğu para, gayrimenkul, hisse senedi gibi fiziksel ve ekonomik kaynaklarla ilgili bir sermaye türü olan ekonomik sermayenin güç ve kudreti meșrulaştıran simgesel işlevleri vardır. ${ }^{26}$

Ekonomik güçle, bunun göstergesi olan simgesel güç arasında karşl1ıklı bir ilişki söz konusudur. Modern dünyada insana saygınlık kazandırdığı varsayılan ekonomik gücün doğrudan doğruya kendisi değil, onun sembolize ettiği güçtür. Günümüzde Mercedes veya BMW marka otomobillerin veya lüks konutların doğrudan doğruya kendileri değil, bunların simgelediği ekonomik göstergeler sahiplerine güç ve saygınlık kazandırmaktadır. ${ }^{27}$

Marxist düşüncede ekonomik sermayenin sürekli artırılmasının zorunlu olduğu kabul edildiği için ekonomik sermaye sahibi aktörlerle diğer sermaye grupları arasında sürekli bir mücadele ve çatışmanın meydana geldiği kabul edilir. Bourdieu bu mücadelenin sadece ekonomik alanda değil, sosyal, kültürel, dinsel, simgesel ve dilsel alanlarda da var olduğunu kabul eder. ${ }^{28}$

22 Espen Jerlang. Et Tekstudvalg, Sociologiske taenkere, Hans Reitzels Forlag, Kopenhag, 2009, s.113-114.

23 Bourdieu Pierre, "The forms of Capital" Handbook of Theory and Research for the Sociology of Education. (Ed. J.G. Richardson), Westport 1986, ss. 85-86.

24 Bourdieu, a.g.e., 1997, s. 95.

25 Bourdieu a.g.e., 1997, s. 52.

26 Larsen og Pedersen, a.g.e., 2011s. 296.

27 Bourdieu a.g.e., 1997, s. 55.

28 Inger Furseth og Pal Repstad, Innföring $i$ Religionssociologi, Universitetsforlaget, Oslo, 2013. ss. 79-80. 
Sosyal sermaye akrabalık, komşuluk, arkadaşlık bağları ve takım ruhu gibi sosyal bağlarla kazanılan bir sermaye türüdür. ${ }^{29} \mathrm{Bu}$ sermaye "bireyin veya grubun karşlıklı ilişkiler zinciri içinde elde ettiği potansiyel kaynakların toplamını" ifade eder. ${ }^{30}$ Sosyal sermayeye sahip olan insanlar sosyal bağları ve ilişkileri sayesinde maddi imkânlar elde etme konusunda kültürel ve ekonomik sermaye sahibi insanlardan daha imtiyazlı konumdadırlar. ${ }^{31}$

Sosyal sermayenin kurumsal türdeki sosyal ağ (network) ile yakın bir ilişkisinin olduğu var sayllır. Bu ağ sayesinde aktör kendisine toplumsal destek bulup itibar sağlama imkânı elde eder. ${ }^{32}$ Sosyal sermayesinin derecesi toplumsal ağın genişliğine olduğu kadar, aktörün ilişkilerindeki yeteneklerine ve ağ içindeki diğer aktörlerin elde ettikleri sermaye oranına da bağlıdır. Toplumsal sermayenin önemli bir etkeni olan sosyal ağ, doğal olarak meydana gelen veya bireyin kendisini doğuştan içinde bulduğu sosyal koşulların tabii seyri içinde değil, arkadaşlar, komșular ve akraba çevrelerinde kurulan formel ve enformel ilişkilerle oluşturulur. ${ }^{33}$ Sosyal sermayenin aktörlerin sosyal yaşamda belli bir konuma gelmelerinde ve konumlarını sürdürmelerinde önemli bir rol oynadığı kabul edilir. ${ }^{34}$

Üçüncü sermaye türü ise këltürel sermaye'dir. Belli bir toplumsal bağlamda aktörün nasıl davranacağına belirleyen kültürel sermaye statü ve güç arasındaki ilişkileri meşrulaştıran bilgi, düşünce, dil kullanımı ve alıskanlar şeklinde tezahür eder. ${ }^{35}$

Ekonomik sermaye doğrudan doğruya maddi kaynaklara sahip olmaya ve onu kullanma özgürlüğünü kapsadığı halde, kültürel sermayenin sembolik bir niteliği vardır. Ekonomik sermaye nakit paraya dönüştürülebilmesine veya mülkiyet hakk1 olarak kurumsallaştır1labilmesine rağmen, kültürel sermaye ancak belli koşullarda ekonomik sermayeye dönüştürülebilmekte veya öğretim nitelikleri biçiminde kurumsallaştırılabilmektedir.

Kültürel sermaye sahibi bireyler belli bir konuda eğitimli olmak, müzik ve resim gibi güzel sanatlardan anlamak, dil bilmek ya da önemli bir konu hakkında bilgi sahibi olmak gibi kültürel niteliklere sahiptir. Kültürel sermayenin

29 Ali Kirman, Din Sosyolojisi Terimler Sözlïğ̈̈, 2. Bask1, İstanbul 2011, ss. 280-281.

30 Bourdieu and Wacquant, a.g.e. s. 83.

Kaspersen og Blok, a.g.e., ss. 71-72.

Jarvinen, a.g.e., s. 370.

33 Staf Callewaert, Kultur, peadagogisk og videnskab. Om Pierre Bourdieus habitusbegreb og praktik teori, Akademisk Forlag, Kopenhag 1992, s. 75.

34 Bourdieu, a.g.e., 2006, ss. 18-20.

35 Lars Bo Kaspersen, "Anthony Giddens", En Intruduktion til en samfundsteoritiker, Kopenhag 2001s. 70 . 
sosyal ve ekonomik sermayeye dönüştürülebildiği ve insanların önem verdiği ilişkiler kurmalarına ve yüksek gelir getiren bir iş bulmalarına fayda sağladığ1 kabul edilmektedir. ${ }^{36}$

Diğer yandan insanın doğumundan itibaren kazanmaya başlayıp, okul ve aile ortamında geliştirdiği ve tüm yaşamı boyunca pekiştirdiği donanımları ifade eden kültürel sermaye, eğitimin sosyolojik analiziyle alakalı bir sermaye türü olarak aktörlerin toplumsal konumlarını güçlendirir. ${ }^{37}$ Eğitim ve öğretimle elde edilen bilgi ve hüner veya sanat eserleri gibi kültürel objelerle nesnelleştirilen bu sermaye gündelik yaşamda içselleştirilip davranış ve oryantasyona dönüştürülür. Kültürel sermaye sahibi kimseler genellikle "kültürel elit”, “aydın”, “yüksek öğretimli” veya "akademisyen” terimleriyle tanımlanırlar. ${ }^{38}$

Dil ve konuşma biçiminde yaşamın erken dönemlerinden itibaren etkin bir rol oynamaya başlayan kültürel sermaye zamanla kişinin "habitus"unun bir parçası haline gelir. Yemek, kıyafet, müzik ve spor gibi olgularla da ilişkilendirilen kültürel sermayenin kazanılıp geliştirilmesinde özellikle öğretim sisteminin önemi vurgulanır. ${ }^{39}$

Bourdieu'nün, toplum analizlerinde üzerinde durduğu önemli bir kavram olan "habitus", sosyal sistemin yeniden kurulumunu sağlayan bir dinamiktir. Belli sosyal grupların davranış modelleriyle alakalı bilgi formları ve eylem modelleri meydana getiren ortak davranışsal eğilimler, bireysel yatkınlıklar ve alışkanlıklar olarak tanımlanan habitus ${ }^{40}$ "insanların sosyal dünyayı yorumladığ içselleştirilmiş zihinsel (mental) veya bilişsel (cognitive) bir yapı"dır. ${ }^{41}$

Bir değer sistemi, norm, alışkanlık, anlayış, tutum, alg1, düşünce olarak habitusun hem insan eylemlerini yapılandırdığı hem de bunlarla yapılandığ

36 Thomas Brante, og Heine Andersen, Leksikon i Sociologi, Akademisk Forlag Kopenhag 2007s. 78.

37 Bourdieu, 2006, a.g.e., ss.141-142.

38 Kaspersen, 2001, a.g.e., 71.

39 Bourdieu og Wacquant, ss. 141-142.

40 Brante og Andersen, a.g.e., ss: 92.

41 Bourdieu'den önce Aristo ve Ortaçağ filozofları Thomas Aquinas ve fenomenolojinin kurucusu Edmund Husserl, hakkında kesin açıklama yapılamayan beşeri tecrübelerin çözümlemesinde habitus kavramından yararlandıkları gibi, kurucu sosyologlardan Hegel, Weber, Durkheim ve Mauss'da çalışmalarında habitus kavramına yer vermişlerdir. 20. yüzyılda ise Fransız filozof Merleau-Ponty (1908-1961) ve Alman filozof Heidegger (18891976), insanın sosyal çevresiyle ilişkisinin araştırılmasında habitus kavramına başvurmuşlardır. (B.k.z. Brante og Andersen, a.g.e., s. 92). 
kabul edilir. ${ }^{42}$ İnsan davranışını anlamak için "aktör ve "yapı" (veya öznelliknesnellik)" öğelerini birleştirmeye yönelik bir çözümleme aracına ihtiyaç duyan Bourdieu, habitus kavramıla klasik sosyolojideki aktör ve yap1 arasındaki geleneksek karşıtlığını gidermeye çalışır. Ona göre beşeri eylemler sadece öznel ve nesnel unsurlardan değil, aynı zamanda rasyonel ve irrasyonel unsurlardan da meydana gelir. ${ }^{43}$

Farklı sermaye tiplerinin insanların habituslarının temelini oluşturduğunu varsayan Bourdieu habitus kavramını sermaye kavramıyla birlikte bir çözümleme yöntemi olarak kullanır. ${ }^{44}$ Sermayenin hacim ve büyüklügünden daha kapsamlı olan habitus geniş anlamda insanların hayatları boyunca elde ettikleri ve elde edebilme gücüne sahip olukları deneyimleri ve birikimleri kapsar.

Habitus ile toplumsal yapı arasında karşılıklı bir ilişki söz konusudur. Bourdieu habitusun hem toplumsal yap1 tarafindan belirlendiği hem de yeni toplumsal yapilar meydana getirdiğini varsayar. ${ }^{45} \mathrm{Bu}$ durumda habitusun bir taraftan toplumsal yapiyı üreten, diğer taraftan da toplumsal yap1 tarafindan üretilen, başka bir ifadeyle dışsallığ içselleştirip içselliği dişsallaştıran diyalektik bir işlevinin olduğu kabul edilir. ${ }^{46}$

Toplumsal yapı ile beşeri eylem arasındaki ilişkiye kültürel açıdan bakma imkânı veren habitus, tekrarlama ve öğrenme sonucu içselleştirilen bilinçli veya bilinçsiz alışkanlıkları ve yapı haline gelmiş olan davranış kalıplarının beşeri bilinç, kişilik, estetik zevkler ve algılarını kapsar. Birer habitus haline gelen alışkanlık ve yatkınlıklar tasnif edici şemalar meydana getiren bir bütünlük oluştururlar. Pratikleri kodlamanın yeterince gelişmediği geleneksel toplumlarda habitus daha açık ve net, modern toplumlarda ise kapalı biçimde tezahür eder. ${ }^{47}$

"Habitus" ile "sermaye" kavramlarını da ilişkilendiren Bourdieu, habitusun değişik sermaye türleriyle somutlaştırıldığını kabul eder. Alışkanlıklarımızı tehdit eden durumlar yaşamaktan kaçındığımız için iş ve arkadaş seçimimiz de "habitus"umuza uygun düşer. Dış koşullara doğrudan doğruya nedensel bir etkisi olmayan düşünce ve eylemlerimizin gerçekleştiği şartlarda ortaya çıkıp ve önyargılarımızı pekiştiren veya yeni açılımlar kazandıran

42 Peter Nörbaek Hansen og Palle Qvist, , Sumfundslex, Gyldendal, Aalborg 2009, s. 172.

43 Nörbaek og Qvist, a.g.e. s.173.

44 Jerlang, a.g.e., s 170.

45 Furseth og Repstad, a.g.e., s. 79.

46 Bourdieu and Wacquant, a.g.e., s. 121.

47 Larsen og Pedersen, a.g.e. s. 221. 
kendi habitusumuzdan tamamen farklı durumlarla karşlaşabiliriz. 48 Son zamanlarda davranış kalıplarında meydan gelen değişim konusunda yapılan araştırmalar Bourdieu'nün habitus modelinde buluşma nedeniyle meydana gelen etkileşimin belirleyici rolü hakkındaki tezini desteklemektedir. Belli bir sosyalizasyon süreci yaşamış olan gençlerin kendi habituslarından farklı habituslara sahip kimselerle buluşmaları nedeniyle davranışlarında ciddi değişimler meydana gelebilmektedir.

Habitusun oluşum sürecindeki etkileşimin önemine dikkat çeken Bourdieu özel durumlarda bireylerin öznel habituslarından hareket ederek belli stratejiler geliştirdiğini kabul eder. ${ }^{49}$ Etkileşimin toplumsal aktörlerin geliştireceği stratejilerin yönünü belirlediğini varsaydığı için de tezine "iradecilik (voluntarism)" unsurunu dâhil eder. ${ }^{50}$

Çocuklar ve gençlerin kendilerine özgü ve zamanla kayıtlı olan farklı habitusları genellikle ebeveynlerinin habituslarının niteliklerini taşır. İnsanların habituslarının bașkalarınınkine benzeyip benzemediği onların habituslarının dıș dünyada başka habituslarla buluştuklarında anlaşılır. Bilinen ve tanıdık ortamlarda bireyler kendilerini güvenli ve mutlu, yabanc1 ortamlarda ise huzursuz ve mutsuz hissederler. İnsanların bilinçli bir hedefi olmadan amaçlarına uygun olarak nasıl eylem yaptıkları sorusunun cevab1 onların habituslarında aranır. Bu durumda habitus, aktörlerin eylem içinde oldukları bir yapılanma mekanizması işlevi meydana getirerek eylemin yönünü belirler. Uyulması zorunlu, açık veya kapalı kurallar olarak tezahür etmeyen habitus pratik ve rasyonel davranışları düzenleyen kurumsal dış yapıların içsel sonuçları şeklinde tezahür eder. Bundan dolayı habitusun alg1, değerlendirme kriterleri ve eylem modelleri gibi bazı ilişkilerden oluşan yapısal bir boyutu vardır. ${ }^{51}$

Özetle habitus insanların tercih yapmalarına ve toplumsal dünyada kullanacakları stratejileri seçmelerine yarayan ilkelerin belirlenmesinde etkin bir rol oynar. İnsanlar, genellikle habitusun ve onun işleyişinin bilincinde olmadıkları halde, o yeme, içme ve yürüme gibi gündelik pratiklerle kendini gösterir. Habitus bir yapı işlevi meydana getirmesine rağmen insanlar habitusa ve onun üzerinde bir fonksiyon oluşturan dısssal yapılara mekanik bir tepki

48 Bourdieu, Pierre, Distinksjonen: En sosiologisk kritikk av drömmekraften, Oversatt, Annick Prieur, Pax, Oslo 1995, s.170.

49 Hansen og Qvist, a.g.e. s. 173.

50 Bireylerin eylemlerinin gerçek failleri olduklarını kabul eden "iradecilik" genel olarak determinizm karşıtı bir içeriğe sahiptir. İradecilik odaklı yaklaşımlarda bireysel amaç, karar ve tercihlerin önemi vurgulanıp bireyin verdiği kararlarda ve yaptı̆̆ işlerde özgür iradenin önemi belirtilir. (Bkz. Bourdieu, a.g.e., 1968, s. 704

51 Bourdieu, a.g.e., 1995, ss.111-112. 
göstermezler. $\mathrm{Bu}$ nedenle Bourdieu beklenmeyen gelişmelerin, öngörülmez yeniliklerin ve toptan belirlenimciliğin aşırılıklarından kaçınmaya özen gösterir. ${ }^{52}$

Bourdieu'nün üzerinde durduğu temel kavramlardan biri de simf (class) kavramıdır. Genel anlamda eşit maddi kaynaklara sahip olan ortak norm ve değer sistemini benimseyen ve aynı yaşam biçimine sahip insanların oluşturduğu bir birliktelik olarak tanımlanan sınıf, özellikle kapitalist toplumlarda bireyler ve gruplar arasındaki hiyerarşik ayrışmayı gösteren ve kapitalist üretim modelinde sıkça kullanılan bir kavramdır. ${ }^{53} \mathrm{Bu}$ kavram sosyolojik olarak, toplumdaki bireyler ve gruplar arasındaki ilişkisel ve hiyerarşik ayrışmaya da işaret eder.

Bu genel ve sosyolojik anlamına ilaveten Bourdieu sınıf kavramını aynı ekonomik imkânlara, ortak değer sistemine ve mizaca, yani habitusa sahip insanlardan meydana gelen birliktelik olarak tanımlar. ${ }^{54} \mathrm{Bu}$ kavram Bourdieu'nün sosyal eşitsizlik ve toplumsal tabakalaşma araştırmalarının da temelini oluşturur. ${ }^{55}$ Bourdieu sınıf kavramını toplumdaki belli grupların güç elde etmek ve elde ettikleri gücü sürdürebilmek için gösterdikleri çabayı analiz etmek için kullanır. Klasik Marxizm'in, sınıfsal farklılıkların toplumsal ayrışma ve çatışmaya neden olduğu görüşünü reddeden Bourdieu Distinction ${ }^{56}$ adlı eserinde, habitus kavramıla işçi sınıfının nesnel ilgilerinin zorunlu olarak sınıf bilincine ve sınıf eylemine dönüştügü fikrine eleştiriler yöneltir. ${ }^{57}$

Bourdieu'ye göre sınıfın oluşmasında onun ayrıcalıklarının ve gücünün önemli göstergeleri olan "gelir" ve "sermaye" gibi dış koşullar değil, sınıfin "genel alışkanlıkları" ve "ortak eylemleri" gibi iç koşullar önemlidir, ${ }^{88} \mathrm{Bu}$ anlamda toplum, güç olgusuna değişik erişim imkânları olan farklı sınıflardan meydana gelen bir birlikteliktir. Modern toplumdaki farklı sosyal sinıfların tüketim kalıpları, boş zaman etkinlikleri, sanat ve giyim tarzları ile toplumdaki habituslar arasında yakın bir ilişki söz konusudur. Söz gelimi özel sektörde çalş̧an bir kadının, öğretim kurumundaki bir öğretmenin, bir TIR şoförünün veya bir maden işçisinin kıyafetleri onların yaşam tarzlarının, yani habituslarının bir göstergesidir. ${ }^{59}$

52 George Ritzer, Modern Sosyoloji Kuramlar, çev. Himmet Hülür, De Ki Yayım Ltd Şt, Ankara 2011. ss. 403-404.

53 Steen Nepper Larsen, og Pedersen, a.g.e., s. 233.

54 Bourdieu, a.g.e. 2006, s. 23.

55 Hansen og Qvist, a.g.e. 2009, ss. 121-122.

56 Bourdieu, a.g.e. 1995.

57 Bourdieu, a.g.e. 2006, s. 24.

58 Brante og Andersen, a.g.e., s.123.

59 Hansen og Qvist, a.g.e. 2009, ss. 222-223. 
Sınıf olgusu ile sermaye grupları arasında yakın bir ilişki bulunduğu için, maddi ve ekonomik şartların toplumsal sınıfın yaşam tarzını da belirlediği kabul edilir. Örneğin zamanının büyük bir kısmını temel gereksinimlerini karşılamak için harcayan işçi sınıfina mensup bir kişi "pragmatist ve pratik bir estetik" geliştirir. Bu estetikte televizyondaki bir magazin programına veya yerel bir reklam gazetesine, Mozart veya Picasso'nun eserlerinden daha fazla önem atfedilir. ${ }^{60}$ Buna karşıllk kültürel sermayeye sahip bir kimse için sanat ve edebiyat gibi güzel sanatlar, ekonomik sermaye sınıfına mensup bir kimse için de lüks ve konforlu yaşam sürmek önemlidir.

Toplumsal gücün analizinde ekonomik koşullara daha fazla önem atfeden geleneksel sosyolojinin tersine Bourdieu sosyal yapılar ve buna bağl1 olarak toplumun güç ilişkilerini dönüştüren sınıf ve bireyler için önemli olan sembolik değerlere odaklanır. Bu değerlerin kuşaktan kuşağa aktarılarak tekrar üretilmesi önemlidir. ${ }^{61}$

Bourdieu'nün toplumsal eylem teorisi ile ilgili önemli çözümleme araçlarından biri de alan (field)" kavramıdır. Aktörler arasında rekabet ve çatışmaların meydana geldiği, yani tarafların kendi ilgi alanlarında sembolik sermaye tekeli oluşturmak için girdikleri mücadelenin sürdüğü yapısal ve sosyal bir mekân olarak tanımlanan alan, içindeki tüm nesne ve insanları etkileyen nesnel bir güçtür. ${ }^{62}$ Diğer yandan alanın değişik konumlar arasında meydana gelen öznel ilişkileri yapılandırdığ1 da kabul edilir. ${ }^{63}$ Bireyin içine girmeden önce yapisallaştı̆̆1, sosyal hayatta önemli bir işleve sahip olan alan konumlar arasındaki sistemli ilişkilerde önemli bir rol oynar. ${ }^{64}$ Sözgelimi bir sağllk sisteminden bahsedildiğinde doktor, hemşire, araştırmacı, sağlık politikacısı, yönetici ve temizlikçi gibi birçok insanı bünyesinde barındıran geniş bir mekân aklımıza gelir. Sağlık sektörü sistemi içindeki tüm aktörler kendilerine özgü kişisel özellikleriyle alana farklı form ve içerikte simgesel sermaye katarlar.

Toplumsal koşullarda gerçek ve yeterli sermayeye sahip olan birey veya gruplar alanda seçkin bir konum elde ederek durumlarını güçlendirebilirler. Alanın kendine özgü niteliği farklı sermaye biçimlerinden hangisinin kabul edilerek değer atfedileceğini ve alan içindeki aktörlerin konumları da onların pozisyonlarını belirler. Mesela aldığı eğitim ve sahip olduğu bilgi nedeniyle

60 Pierre Bourdieu, Distinction. A Social Critique of the Judgement of Taste. Cambridge, 1984. s.376.

61 Danielsen, Arild og Marianne, Nordli Hansen, "Magt i Pierre Bourdieus sosiologi", i Om magt: Teori og kritike, (redieret av Fredrik Engelstad), Gyldendal, 1999 s.70-71.

62 Kaspersen og Blok, a.g.e., s. 75.

63 Larsen og Pedersen, a.g.e., s.159.

64 Broady, a.g.e., 183. 
sağlık sistemi içindeki bir doktor bir hemşire ve hasta bakıcıya göre daha güçlü bir konuma sahiptir.

Bourdieu, alan kavramının çözümlemesinde, aktörü yapısal koşullardan ayrı düşünmenin doğru olmadığını savunarak, "yapı" ile "aktör" arasındaki ayrıma karşı çıkar. Ona göre alanda sürekli devam eden sosyal ilişkiler içinde birbirlerini karşıllklı olarak etkileyen "aktör" ve "yapı" kategorilerinin farklı şekillerde konumlandırılması doğru değildir. ${ }^{65}$ Bunların karşılıklı etkileşim içinde bir bütünlük oluşturduğu kabul edilmektedir.

Özetle Bourdieu'nün alan kavramıyla ilgili düşünceleri Marx’tan çok Weber’in düşüncelerine yakındır. Sosyal hayatın yalnızca ekonomik faktörler ve sınıf çatışmaları açısından ele alınamayacağını ifade eden Bourdieu, Marx'ın üst yap1 olarak tanımladığ1 eğitim, kültür, din ve ahlak gibi faktörlerin toplumsal yaşamda önemli rol oynayabileceğinin altını çizer. ${ }^{66}$

\subsection{ANTHONY GIDDENS}

Öncelikle tarih, psikoloji, antropoloji ve siyaset bilimi (politoloji) alanlarında disiplinler arası çalışmalar yapan Giddens, klasik sosyolojideki kuramsal karşıtlığı gidermek için yapılaş(trr)ma (structuration) adını verdiği bir teori geliştirmiştir. ${ }^{67}$ Onun sosyolojisinin anahtar kavramlarından biri olan yap1 (structur) kavramı sosyal sistemleri oluşturan uygulamaların hem kaynağı hem de sonucudur. ${ }^{68}$ Klasik sosyolojide uyumlu ve dengeli ilişkilerle birbirlerine bağlı unsurlardan oluşan bir bütün olarak tanımlanan yap1 kavramı Giddens'in kavramsallaştırmasında determinist değil, aynı zamanda hem "zenginleştirici ve mümkün kilıcı (enabling)" hem de "sınırlandırıcı ve imkânsızlaştırıcı (constraining)" bir niteliğe sahiptir. ${ }^{69}$

Yapı/sistem ve eylem/aktör arasındaki ikiliği gidermek için Giddens yapilarin toplumsal sistemleri meydana getiren fiillerin hem araci hem sonucu olduğunu, sosyal sistemleri oluşturan ve yeniden üreten yapiların insanların pratiklerini biçimlendirdiğini kabul etmektedir. ${ }^{70}$ Söz gelimi bir dili konuşan insan düşüncelerini anlaşlır biçimde ifade etmek (eylem) için bazı gramer kurallarına uymak suretiyle hem dilin kurallarını, hem de onun yapısını yeniden

65 Kaspersen, og Blok, a.g.e. s. 74.

66 Bourdieu, a.g.e., 1999, s. 71.

67 Anthony Giddens, , The Constitution of Society: Outline of the Structuration, Cambridge University Press, Cambridge 1984.

68 Anthony Giddens, A Contemporary Critique of Historical Materialism, London, 1981, s. 27.

69 Anthony Giddens, Capitalism and Modern Social Theory, Cambridge University Press, Cambridge 1989.

70 Giddens, a.g.e., 1981., ss. 27-28. 
üretir. Normal olarak düşüncelerin ifade edilmesine yarayan dil bir araç olmakla birlikte, düşünce ve isteklerin kelimelerle ifade edilemediği veya başkalarının aktörü anlayamadığı durumlarda, "zenginleştirici ve imkân sağlayıcı" olma niteliğini kaybetmektedir.

Giddens, klasik sosyolojideki düalizmin aktör ve eylem, yapı ve sistem kavramlarının yeniden tanımlanıp yorumlanmasıyla olduğu kadar, klasik sosyolojideki aktör ve yapr arasındaki ikiliğinin, bunların birbirlerinin alanlarına müdahale etmemekle aşılabileceğini kabul eder. ${ }^{71} \mathrm{Bu}$ tezini Giddens, Paul Willis,' $1 n^{72}$, Londra'da bir okulda işçi çocukları üzerine yaptı̆̆1 araştırmaya dayandırır. Willis araştırmasında öğrencilerin (yani aktörlerin) okulun kurallarına (yap1/sistem) uymayarak kendilerine göre bir "karşı kültür" geliştirdiği sonucuna varır. Bu örnekteki öğrencilerin okulun geleneksel değer sistemi ve kurallarına karşı gelme eyleminden yola çıkan Giddens, okulun kurumsal yapisının sistem içindeki aktörlerin davranışlardan bağımsız olmadı̆̆ sonucuna varır. Burada okulun düzenleyici kurallar sisteminin hem kendini yapılaştırdığ hem de aktörlerin eylemlerinin niteliğini değiştirdiği kabul edilir. ${ }^{73}$ Örneğin erkek öğrenciler tuvalette sigara içerek yönetmeliklere karşı geldiklerinde, yani bir yasağı ihlal ettiklerinde kurallar sistemi yeniden üretilip yapılaşmaktadır.

Giddens'in bu örnekten yola çıkarak geliştirdiği yapılaștırma teorisi fiilen olup bitenlerle alakalı açık hipotezler ortaya koymaktan çok sosyal çevrede meydana gelen eylemleri çözümlemeyi amaçlar. O, toplumsal olayların her zaman bir "zorunlu karşıtlık" içerdiğini, yani açık uçlu olduğunu varsayarak kapalı sistem olarak gördüğü pozitivist sosyolojinin dayandığ1 "evrim" ve "işlevselcilik" teorilerine karşı çıkar. ${ }^{74}$ Toplumsal yapıların, aktörlerin dışında değil onların kendi pratik ve eylemleriyle üretildiğini kabul ederek yapıları üreten ve yapılar tarafindan üretilen toplumsal eylemler konusunda "eylem" ile "yapı" arasındaki geleneksel ikiliği gidermeye çalısır.

Aktör ve yapr olgularının karşılıklı olarak birbirlerini etkilediklerini varsayan Giddens'in asıl üzerinde durduğu konu “aktör"ün fiilleridir. Geleneksel işlevselcilikte aktör, sistemin ürünü ve sisteme bağlı olduğu kabul edilmesine karşın, Giddens’in yaklaşımında aktör bilgili, yetkin ve iradeli bir varlıktır. Yetkinlik ve iradelilik özellikleri aktörün günlük eylemlerinde başvurduğu sistemsiz bilgilerin depolandığı pratik bilincinde yer alır. Örneğin taşıt

71 Ritzer, a.g.e., s. 84.

72 Paul Willis, Learning to Labour. How Working Class Kids get Working Class Jobs, Farnborough 1977.

73 Willis, a.g.e.,. s. 79.

74 Anthony Giddens, Modernitet og Selvidentitet: Selvet og Samfundet under-senmondernitet, Oversatt av Sören Schultz Jörgensen, Hans Reitzel, Kopenhag. 1996. ss. 226-227. 
kullanmak veya alış veriş yapmak gibi eylemler aktörün bedeninin anatomik ve fizyolojik süreçlerinin işleme tarzıyla alakalı sistemli bilgiye sahip olmadan yaptığ1 fiillerdir. Başka bir ifadeyle aktörler bu eylemleri sistemli bir temele dayanmayan pratik bilinçlerine göre gerçekleştirilmektedir.

Aynı şekilde okulun kurallanına uymayan öğrenciler aslında yaptıkları eylemin yanlışlığını, okul yönetimiyle çatışmaya girmemeleri gerektiğini ve kurallara uymadıkları takdirde nasıl bir yaptırımla karşılaşacaklarını bilmelerine rağmen, pratik bilinçlerindeki sistemsiz bilgiye rağmen eylemlerini gerçekleştirmektedirler.

Aktörlerin yetkinliklerinin başka bir boyutu da onların eylemlerini yansitan bir bilgi türü olan söylemsel bilgi (discursive knowledge)'dir. Kurallara uymayan öğrencilerin davranışlarının nedenleri araştırıldığında, onların otoriteye karşı gösterdikleri tepkileriyle alakalı bir açıklamalarının olduğu görülür. Aktörün söylemsel bilgi düzeyi ve eylemlerini irdeleme yeteneğine sahip olduğunu ortaya koyan bu durum eylem sürecinin farklı boyutlarını ortaya koyar.

Aktörün gündelik eylemlerinde kullandığ1 genel bilgi stoku onun "dönüşümlü” (transformative) olarak düzenlemesini sağlar. Her zaman kendi eylemlerini düzenleyen bir dönüşümlülüğe sahip olan aktör başkalarının da bu şekilde davranacağını düşünür. Dönüşümlü eylem düzenlemesinin pek çoğu, yeteneklerin söylemsel olarak ifade edilmediği pratik bilinç düzeyinde meydana gelir. Sözgelimi kaldırımdan aşağı doğru yürürken karşıdan bir kişinin bize doğru geldiğini gördüğümüzde gayri iradi ona çarpmadan geçmek isteriz. Bir aktör olarak yeteneğimizi kullandığımız böyle bir pozisyonda muhatabımızın da aynı şekilde davranacağını düşünür ve öyle yapmasını bekleriz.

Aynı şekilde gündelik yaşamdaki birçok eylemin bilinçsiz güdüler sonucu meydana geldiğini kabul eden Giddens farklı niyetler, nedenler ve güdülere ayrilmayan homojen davranışlar olarak tanımladığı aktörün eylemini durmadan devam eden bir süreç olarak görür. ${ }^{75}$

Eylemin dışında olan "yapı" ise aktörün eylemini pratiğe dönüştürdüğü alan olan, sistem ise eylemin sınırlarını belirleyen bir mekândır. ${ }^{76}$ Eğitim, sağlık, aile ve devlet gibi sosyal sistemler aktörlerin çalışmalarıyla üretildiği halde, yapı kavramında bir aktör veya nesneden söz edilemez. Öğrencilerinin okul yaşamında karşı çıktıkları güç yapısında bir aktör veya nesne mevcut değildir.

75 Anthony Giddens, Modernitets konsekvenser, Oversatt av Are Erikson, Pax Forlag, Oslo 1996. s. 240-241.

76 Anthony Giddens, The Constitution of Society: Outline of the Theory of Structuration, Berkeley 1984, s. 143. 
Bunlar, öğrenciler ve öğretmenlerin meydana getirdikleri yapısal modeller değil, zihinde tasarlanan kavramsallaştırmalardır. ${ }^{77}$

Yap1 veya yapılaşan sistemler (kural ve kaynaklar) benzer toplumsal pratiklerin çeşitli zaman ve mekânda var olmalarını mümkün kılan ve onlara biçim veren özelliklerdir ${ }^{78}$. Kural ve kaynaklar yapıyı mümkün kılmakla birlikte zaman ve mekânda var olmayan yapılar toplumsal fenomenlerin yapılanmış niteliklerini taşır. Giddens'in yapının bireylerin eylemlerinden bağımsız olmadığını kabul eden modeli yapıyı bireysel eylemlerin dışında ve onu kuşatıcı ve zorlayıc1 bir unsur olarak gören Durkhem'in modelinden farklıdır. Durkhem'in yaklaşımında yapı aktörlerin üstünde ve onları kuşatan bir sistem olarak görülmesine karşın Giddens yapının insan eylemlerinin dışında olduğu tezini reddeder. ${ }^{79}$ Giddens’in yeniden tanımladığ1 “eylem" ve "aktör" kavramları toplumun yapısal sürecini anlamamıza yardım eden enstrümanlar ki bunlarla hangi eylemlerin özel sosyolojik sistemleri meydana getirdiği anlaşılabilir.

Giddens'in sosyolojik kuramlarında işlevselcilik ile eylemcilik arasındaki ikiliği gidererek onları birleştirme çabaları öne çıkmaktadır. ${ }^{80} \mathrm{O}$ bu şekilde toplumların kurumsal işlevleriyle aktörlerin anlamsal değişim alanını birleştiren yeni bir yöntem geliştirmeyi amaçlamaktadır

\subsection{JÜRGEN HABERMAS}

Frankfurt Okulu'nun ikinci kușak düșünürlerinden olan Hebarmas'in teorik çalısmaları Alman felsefesinin ve klasik sosyolojisinin özelliklerini taşır. Özellikle iletişimsel eylem teorisiyle ${ }^{81}$ tanınan Habermas sosyolojik çalışmalarında büyük ölçüde Kant, Hegel, Marx, Weber, Durkheim, Mead ve Parsons'un fikirlerinden etkilenmiştir. ${ }^{82}$ Habermas sosyolojide sistem kuramciları olarak bilinen Marx, Durkheim ve özellikle Parsons'un teorilerinden yola çıkarak yeni bir kavramsal yöntem geliştirmiştir. Rasyonalist düşünceyle alakalı çözümlemeleri genellikle Weber'in çözümlemeleriyle örtüşmekle birlikte Habermas, Weber ekolüne mensup bir sosyolog olarak kabul edilmemektedir. ${ }^{83}$

\footnotetext{
Giddens, Anthony, New Rules of Sociological Method: A Positive Critique of Interpretive Sociologies, London 1976, s. 118.

78 Giddens, a.g.e., 1976, s. 17.

79 Giddens, a.g.e., 1985, a.g.e., s. 56.

Kaspersen og Blok, a.g.e. 2011, s. 73.

81 Jürgen Habermas, The Theory of Communicative Action, Lifeworld and System, A Critique of Functionalist Reason, Beacon Press, vol. II, Boston 1987, ss. 75-76.

82 Kaspersen og Blok, a.g.e., 2011, s. 75.

83 Ruth A. Wallace and Wolf, Alison, Cağdas Sosyoloji Kuramlar, çev. Leyla Elburuz ve M. Rami Ayas, İzmir 2004, s. 208.
} 
Onun akılcıllı̆ı Weber'de olduğu gibi anlama (verstehen) temeline değil, diyalog ve tartışma temeline dayanmaktadır.

Habermas, Theorie des kommunikativen Handelns, 1981 (Iletişimsel Eylem Teorisi) adlı eserinde, Bourdieu ve Giddens'in yaptığı gibi aktör-yap1 karşıtlığını gidermeye çalışır. O'na göre başarı elde etmeye değil, karşıllklı etkileşim ve anlaşmaya yönelik söz ve eylemlerle koordine edilen "iletişimsel eylem" (communicative action) toplumsal iletișimin farklı bir türüdür. Bu eylemde karșllkklı bilgi paylaşımıyla, gerçeklik, haklılık ve ahenk özellikleri bazında bir görüş birliği söz konusudur. ${ }^{84}$

Habermas akılcılığa önem vermekle birlikte, dünyanın giderek artan rasyonelleşmesini sorunlu bir gelişme olarak görmektedir. ${ }^{85}$ Weber'in bürokrasi ve amaçsal akılcıllı̆ı bir "demir kafes” meydana getirmesine karşın, Habermas'ın iletişimsel akılcıllğında böyle bir durum söz konusu değildir. ${ }^{86}$ Weber'den farklı olarak Habermas toplumsal yaşamı, "amaçsal rasyonel eylem" ve "iletişimsel eylem" olarak iki grupta ele alır. Weber'in "rasyonel eylem" tezine benzeyen amaçsal rasyonel eylem modeli kendi içinde "stratejik" ve "araçsal eylem" olmak üzere iki kategoriden oluşur. Söz gelimi yeni bir işe başvuran bir kimsenin rakiplerinin dilekçelerinin nasıl biçimlendirdiklerini ve gönderilen dilekçelerin işveren tarafından nasıl karşılandığını hesap ederek dilekçesini biçimlendirmesi "stratejik bir eylemdir". Fakat örneğin aktörün sandalye yapımı için hangi araçların gerekli olduğunu hesaplaması şeklindeki fiziksel duruma yönelik bir eylem ise "araçsal eylemdir". ${ }^{87}$

Habermas'n üzerinde durduğu "iletişimsel eylem", aktörlerin kişisel çıkar hesapları üzerine değil, anlama ve sosyal etkileşim üzerine dayanan bir eylem türüdür. Bu eylemde aktörler çıar amaçlı başarıya değil, ortak durum tanımlamaları paydasında birbiriyle uyumlu amaçlara yönelirler. Amaçsal eylem fiziksel ve maddi bir amaca, iletişimsel eylem iletişimsel ise anlamaya yöneliktir. ${ }^{88}$ Çıkar hesaplarına değil, karşılıklı anlayış ve yönelimlerine dayanan iletişimsel eylemde aktörler, dilsel iletişimle anlaşabildikleri için aralarında gerçekleșen diyalog önemli bir taşıyıcıdır. Eylemin gerçekleşmesinin ön koşulu iletișim için gerekli olan dilin varlığ değil, ortak norm ve değer sisteminin varllğıdır. Örneğin bir grup gencin saat 17.00 'de futbol oynamak üzere

84 Jürgen Habermas, Communication and the Evolution of Society, transl. Thomas McCarthy, Heinemann, London 1976, s. 3.

85 Jürgen Habermas, Religion and Rationality. Essays on Reason, God, and Modernity, transl. Eduardo Mendieta, Polity Press, Cambridge 2002.

86 Wallace and Wolf, a.g.e., s. 210.

87 Kaspersen og Blok, a.g.e., ss. 76-77.

88 Jürgen Habermas, The Theory of Communicative Action, Reason and the Rationalization of Society, Boston 1984, s. 278 
anlaşmaları ve anlaştıkları saatte buluşmaları "normatif ve değersel birlikteliğin" var olduğunu gösterir. Bu birliktelik, gençlerin aralarında tartışarak belli bir zamanda futbol oynama konusunda görüş birliğine varmayı mümkün k1lacak değerlerin varlığına işaret eder. Burada bireysel çıkarların değil ortak bir amaç ve eylem birliğinin varliğı söz konusudur.

"Amaçsal rasyonel eylem" ve "iletişimsel eylem" kategorileri açısından toplum deneyim dünyasına atfedilen fenomenolojik bir kavram olan yaşam dïnyası (lifeworld) ve sistem (system) olmak üzere iki açıdan ele alınır. ${ }^{89}$ Amaçsal rasyonel eylem sistemi, içsel ve öznel iletişimsel eylem ise yaşam dünyasını temsil eder. Dışsal ve nesnel bir temele dayanan amaçsal eylem aynı anda hem sistemi oluşturur hem de sistem tarafından oluşturulur. Yaşam dünyası ise öznel ve nesnel bir bakış açısına dayanır. ${ }^{90}$ İletişimsel eylemin meydana geldiği yaşam dünyası ile amaçsal eylemin meydana geldiği sistem gerçekte birbirlerinin karşıtı değil tamamlayıcısıdırlar. Birbirlerini hem sınırlandıran hem de birbirlerine yeni imkânlar sağlayan sistem ve yaşam dünyası kategorileri arasında diyalektik bir ilișki söz konusudur. Yaşam dünyası, içinde hem dinleyenin hem de konuşanın buluştuğu ve söyleşilerinin dünyaya (sisteme) uyduğu bir mekân olarak algilanir. ${ }^{91}$

Habermas'n sistem” ve "yaşam dünyası" kavramları aktör-yapı ikiliğini ortadan kaldırıp bunları tek birim haline getirmeyi hedefler. Sosyolojik olarak hermeneutik, fenomenoloji ve sembolik etkileşim teorileriyle somutlaştırılan yaşam dünyası Habermas'ın kullanımıyla yeni bir muhteva kazanır. Bu yöntemle toplumun öznel yönünün, yani eylem boyutunun önemini vurgulayan Habermas topluma katılımcı açıdan (aktör cephesinden) bakar. Bu şekilde toplumsal dünyanın bir bölümü iletişimsel eylemlere dönüşür ve bu eylemler ortak ve kesin arka plan bilgisiyle uyumlu hale gelir. ${ }^{92}$ Verdiğimiz örnekte görüldüğü gibi futbol oynamak üzere anlaşan gençler eylemlerini ortak bir dil ve kültür haline gelmiş olan bilgi aracillğıyla gerçekleştirirler. Ortak bellekte saklanan bilgi paydaş yaşam dünyası olarak görüldüğü için yaşam dünyası insan eylemlerinin temelini oluşturur.

Habermas'ın yaşam dünyası kavramı bir ölçüde Bourdieu'nün "sermaye" ve "habitus" kavramlarına benzemektedir. Yaşam dünyası (sermaye/habitus) bir yandan aktörü belli bir eylemle sinırlandırırken diğer yandan ona yeni imkânlar sağlar. Bu şekilde aktörün aynı anda hem eylem yapan

89 Marshall, a.g.e., s. 813.

90 Habermas, Jürgen, The Theory of Communicative Action, Lifeworld and System, A Critique of Functionalist Reason, Boston 1987, s. 117.

91 Habermas, a.g.e., 1987, s. 126.

92 Habermas, a.g.e., 1981, ss.196-197. 
(etkileyen) hem de daha önceki eylemlerin ürünü (etkilenen) bir varlık olduğu var sayllir. ${ }^{93}$

Habermas açısından bir toplumun özelliklerinin (yani sistemin) belirlenmesi için yaşam dünyasının yeniden oluşturulmasını (reproduction) ve sürdürülmesini anlamak gereklidir. Yaşam dünyasının yeniden oluşturulmasının ve sürdürülmesinin en önemli aracı dildir. Ancak bu süreçte etkili olan başka faktörler de vardır. Bu noktada iletişimsel eylemlerin kültürel bilginin aktarılıp yenilenmesine, toplum üyeleri arasında dayanışma sağlanmasına ve sosyalizasyon süreçleriyle bireysel kimliğin geliştirilmesinde etkin bir rol oynadığ 1 kabul edilir. ${ }^{94}$

Yaşam dünyas1, aksiyon halindeki aktörün toplumla ilgili öznel düşüncelerine işaret etmesine karşın, sistem dışsal bakış açısını temsil eder. ${ }^{95}$ Toplumun kişilik ve kültür gibi yaşam dünyasının önemli bileşenlerinin sistem içinde her birine karşllı gelen öğeleri vardır. Kültürün yeniden üretimi, toplumsal bütünleşme ve kişilik oluşumu sistem içinde meydana gelir. Kökleri yaşam dünyasında olmayan sistem aile, yarg1, devlet ve ekonomi gibi kendine özgü yapısal kurumlar oluşturur. Ancak bu yapısal özellikler zamanla evrimleșip geliştikçe sistem yaşam dünyasından uzaklaşmaya başlar. ${ }^{96}$ Rasyonelleşme yaşam dünyasında olduğu kadar sistem üzerinde farklılaşma ve karmaşıklığa yol açar. Zaman içinde kendine yeter hale gelen yapiların gücü arttıkça sistem yaşam dünyası üzerinde egemen olmaya başlar. Rasyonel yapılar, iletişim kurma ve anlaşmaya varma gibi içsel olguları güçlendirmek yerine, dışsal kontrolü artırarak süreci tehdit eden birer unsur haline gelirler. ${ }^{97}$

"Yaşam dünyası" ve "sistem" geleneksel toplumlarda birbirleriyle ilişkili ve birbirlerine yakın oldukları halde modern dünyada bunlar arasında gittikçe artan bir uzaklaşma ve ayrışma yaşanır. Ayrıca modern toplumun temel özelliklerinden olan rasyonelleşme bu olguların niteliklerini de değiştirir. ${ }^{98}$

Modern dünyada sistemin yaşam dünyasına hakim olması yani sistem ile yaşam dünyası arasındaki diyalektiğin kaybolması sistemin yaşam dünyası üzerindeki gücünü artırmasına neden olur. Habermas'a göre kapitalizm

\footnotetext{
93 Larsen, Pedersen, a.g.e, 2001, s. 221

94 Habermas, a.g.e., 1981, ss. 205-207.

95 Habermas, a.g.e., 1987, s.117.

96 Habermas, a.g.e., 1987, ss. 117-118

7 Habermas, a.g.e., 1987, s. 119.

98 Ritzer, a.g.e., 2011, s. 407.
} 
sonras ${ }^{99}$ toplumların en ciddi problemlerinden biri sistemin yaşam dünyasına egemen olmasıla birlikte, bu iki birim arasındaki dengenin bozulmasıdır. Modernleşme süreçleriyle birlikte amaçsal rasyonel eylemlerin iletişimsel eylemlere egemen olması yaşam dünyasını ortadan kaldırmaktadır. ${ }^{100}$ Amaçsal akılc1lığın, iletişimsel akılcıllğa egemen olması sadece kamu kurumlarının değil, sivil kuruluşların da rasyonelleșip profesyonelleşmesine ve ekonomik gücün giderek önemli bir yönetim faktörü haline gelmesine neden olur. Yaşam dünyasının yok olmasıyla sonuçlanan bu gelişme, birey için anlam ve kimlik kaybına, sembolik olarak kendini yeniden üretemeyen toplum için de "anomi"ye yol açar. ${ }^{101}$

Çağdaş dünyada birçok yeni akımın ortaya çıkmasının nedeni yaşam dünyasının sistemin kontrolüne girerek yoksullaşmasıdır. Modernleşme ile birlikte gücünü artıran amaçsal rasyonelliğin yaşam dünyasındaki iletişimsel eylemler üzerindeki etkisini artırması bu yeni akımların ortaya çıkmasında etkin bir rol oynamaktadır.

\subsection{JAMES S. COLEMAN}

Konuyla ilgili üzerinde duracağımız sosyologlardan biri olan Amerikalı James S. Coleman (1926-1995) metodolojik bireyciliğin, başka bir ifadeyle sübjektif bakış açısının özel bir formu olan akulcu sȩ̧im teorisi (rational choice theory) üzerinde çalışmıştır. Sosyal bilimlerde önemli bir paradigma haline gelen bu teori büyük ölçüde Coleman'in çalısmalarıyla modern sosyolojiye taşınmıştır. ${ }^{102}$ Coleman, Foundations of Social Theory (1990) adlı eserinde bireysel ve rasyonel davranış temeline dayanan kavramsal çerçeve ile "sosyal davranış" ve "yapı" arasındaki ilişkileri incelemiştir. 103

$\mathrm{Bu}$ teorinin kaynağı, toplumsal aktörlerin ekonomik tercihlerini maksimum faydayı göz önüne alarak yaptıklarını kabul eden Klasik ve Neoklasik Ekonomi ye dayanır. Aynı düşünceden yola çıkan Coleman, aktörlerin ilgi alanları ve koşulların kendilerine tanıdığı imkânlar çerçevesinde en rasyonel tercihleri yaptıklarını kabul eder. ${ }^{104}$ Buna göre toplumsal yaşamın bireylerin çıkarlarını en

\footnotetext{
99 Yirminci yüzyılın son çeyreğinden itibaren kristalize olan toplumsal koşullar, "Sanayi Sonrası", "Post-Modernizm", "Post-Fordizm", "Geç Kapitalizm", “Geç Modernizm” kavramlariyla ifade edilmektedir.

100 Ritzer, a.g.e., ss. 431-432.

101 Ritzer, a.g.e., s.432.

102 James S Coleman, "Social Theory, Social Research, and a Theory of Action", American Journal of Sociology vol. 91, nr.6. 1309, s.13.

103 Ritzer, a.g.e., s. 304.

104 Kaspersen og Blok, a.g.e., 2011, s. 83.
} 
üst düzeye getirme, kaynakları en verimli şekilde kullanma ve gerektiği yerde değiştirme çabalarılyla biçimlendiği kabul edilir. ${ }^{105}$

Akılcı seçim teorisine eleştiriler de yapılmıştır. Sosyal sistemlerin nasıl işleyip değiştiğini araştırmak sosyolojide önemli bir konu olduğu için sadece iki kişi arasında mikro düzeydeki yalıtılmış ilişkiye bakmak yeterli görülmemektedir. Sosyal sistemlerin nasıl çalıştı̆̆ını anlayıp yorumlamak için toplumsal süreçlerin mikro ve makro düzeydeki ilişkilerini çözümlemek önemlidir. Coleman, kendisinden önce makro-mikro ikiliğini aşmak için yapılan sosyolojik çalışmalara örnek olarak Weber'in, Kapitalizm’in Batı Avrupa'da ortaya çıkışı hakkında türettiği teorileri ele almıştır.

Coleman, Weber'in makro-mikro ikiliğini aşmak için geliştirdiği modelin temelinin kullanışlılığını kabul etmekle birlikte, onun analizlerini yeterli bulmamaktadır. ${ }^{106}$ Coleman'a göre Weber'in, diğer mezheplerden farklı değerler ihtiva ettiğini varsaydığı Protestanlığın müntesiplerinin özel davranış modelinin, Protestan toplumlarda kapitalist bir sistem meydana getirdiği varsayllmaktadır. ${ }^{107}$ İki aşamalı olarak gerçekleşen bu sürecin ilk aşamasında Protestanlık mikro düzeyde bir değerler sistemi oluşturduğu, ikinci aşamasında ise müntesiplerin ekonomik eylemlerinin makro düzeyde kapitalist bir sistem meydana getirdiği kabul edilmektedir. ${ }^{108}$

Coleman, Weber'i, aktörlerin eylemlerinin niçin makro sosyolojik sonuçlar meydana getirdiğini netleştirmemekle eleştirerek onun yaklaşımını yetersiz bulmaktadır. ${ }^{109}$ Coleman'a göre Weber'in, bireylerin mikro düzeydeki pratikleri birleştirme örneği makro düzeydeki kolektif durumu açılamadığ1 gibi, eylemlerin birleştirilerek sistem üzerinde niçin bir etki meydana getirdiğini de açılamamaktadır. Ona göre iki farklı kişinin yaptığı eylem zorunlu olarak aynı amaca yönelik olmadığı gibi, aynı motivasyona da sahip değildir. Örneğin işçi ile işverenin veya öğretmen ile öğrencinin eylemlerinin motivasyonlarının zorunlu olarak örtüştüğünü söylemek güçtür. Bu örneklerle Coleman aktörlerin eylemlerindeki niyet ve motivasyonlarının otomatik olarak aynı hedefe (yani kapitalist bir sistem oluşturmaya) yönelik olmadığını savunmaktadır. ${ }^{110}$

\footnotetext{
105 James S. Coleman, Foundations of Social Theory. Harvard University Press, Cambridge 1990, s.29.

106 Coleman, James S., "Microfoundation and Macrosocial Behaviour", The Micro-Macro Link (Ed. J.C. Alexander), University of California Press, Berkeley 1987, s._153.

107 Coleman, a.g.e. 1987, ss. 154-155.

108 Coleman, a.g.e., 1987ss. 154-155.

109 Coleman, a.g.e., s. 153.

110 Larsen og Pedersen, a.g.e., 2011. s. 97-98.
} 
Coleman, Weber'in tezindeki makro-mikro ikiliğini gidererek bir bütünlüğe ulaşmak için geliştirdiği yeni tezini şu örnekle açıklar. Seyirci dolu bir tiyatroda birdenbire duyulan bir yangın alarmı seyircilerin (yani aktörlerin) farklı tepkiler vermesine neden olur. Bu durumda seyirciler duydukları yangın alarmı karşısında paniğe kapılabilecekleri gibi, soğukkanlı bir tutum da sergileyebilirler ${ }^{111}$ Duydukları yangın alarmı karşısında insanlar rasyonel olarak şu tepkileri verebilirler. 1. Paniğe kapılarak dışarı koşmak 2. Sakin ve soğukkanlı bir biçimde salonu terk etmek 3. Başkalarının yaptı̆̆ını örnek alıp aynı eylemi (1. ve 2 . durumdakinden birini) yapmak.

Üçüncü seçenekte aktörler, başkalarının belli bir durumda yaptıkları tercihleri en iyi tercih olarak görmelerine karşın, birinci ve ikinci seçenekte kararlarını kendileri vermekte, yani Akılsal Seçim Teorisi'ne göre kendilerince en rasyonel olan fiili yapmaktadırlar. ${ }^{112} \mathrm{Bu}$ örnekle Coleman bir yandan aktörlerin hangi rasyonel tercihler yapabileceklerini ve olası sonuçların hangi kolektif davranışlara yol açabileceğini, diğer yandan da paniğin niçin çıtığını ve ortak bir eyleme dönüştügünü açıklamak ister.

Ancak Coleman'ın, Weber'in teorisini eleştirmeye yönelik olarak sergilediği tutum üç açıdan yetersiz bulunmaktadır. Birincisi, mikro komundan makro konuna geçiş ilişkisine aşırı derecede önem verilerek diğer ilişkilerin görmezlikten gelinmesi; ikincisi nedensel odaklı ilisskilerin tek yönlü açıklanması; üçüncüsü de, mikro-makro olgular arasındaki diyalektik ilişkiye yeterince önem verilmemesidir. ${ }^{113}$ Coleman'ın, mikro-makro karşıtlığını gidermek için verdiği yangın alarmı örneği de aktörlerin akılcıllğını ve amaca yönelik eylemlerini yeterince açıklamamakla eleştirilmektedir. ${ }^{114}$

\section{SONUÇ VE DEĞERLENDİRME}

Yukarıda yaptığımız analizde görüldüğü gibi Pierre Bourdieu, Anthony Giddens, Jürgen Habermas ve James S. Coleman'ın sosyolojide aktör-yapı, mikeromakro ikiliğini aşmak için farklı isimler altında geliştirdikleri yeni kavramlar birçok noktadan örtüşmektedir.

Pratik enstrümanlar olarak kabul ettiği sermaye, habitus, sinıf ve alan kavramları üzerinde analizler yapan Bourdieu toplumsal gerçekliğin kavranmasında sadece öznel ve nesnel bilgi formlarının yeterli olmadığını ve

111 Coleman, a.g.e., s. 155.

112 Coleman'a göre aktörlerin akılcı tercihlerinin sonucu meydana gelen "panik" veya "sükûnet" makro fenomenlerdir. Bkz. Larsen og Pedersen, a.g.e., 98.

113 Ritzer, a.g.e. 2011, s. 308.

114 Ritzer, a.g.e. 2011, s. 309. 
sosyolojideki nesnelcilik-öznelcilik karşıtlı̆̆ının ancak bunların birbirlerini tamamlayacak şekilde açıklanıp yorumlanmasıyla aşılabileceğini öngörmektedir. Mikro-makro ve eylem-yapı ikiliklerine karşı çıan Bourdieu bu kategorilerden birini ötekine tercih etmenin doğru olmadığını ve bunların birleştirmesinin gerekliliğini vurgulamaktadır.

Yapısalc1lı̆̆1 bireyin seçme ve eylem özgürlüğünü kıstlamakla, eylemciliği de toplumsal gerçekliği önemsemekle eleştirtiren Bourdieu bir yandan bireysel eylemlerin toplumsal yapıdan etkilendiğini savunarak Durkheim ve Marx'ın düşüncelerine yaklaşırken, diğer yandan bireyin eylemlerinde toplumsal yapıdan bağımsız olduğu görüşüyle Weberci bir tutum sergilemektedir. Kuramsal kavramsallaştırmlarını ampirik araştırmalarla destekleyen Bourdieu habitus, sermaye ve alan kavramları üzerine yaptığ1 çözümlemelerle hem nesnelliğe hem de öznelliğe alternatif olacak özgün yaklaşımlar geliştirmektedir.

Giddens ise klasik sosyolojinin düalizminin ancak aktör ve eylem, yapr ve sistem kavramlarının yeniden tanımlanıp yorumlanmasıyla ve geleneksel sosyolojideki aktör-yapı ikiliğinin, sistem ve aktörlerin karşllklı olarak birbirlerinin eylemlerini belirlemeden aşllabileceğini savunmaktadır.

Giddens teorisinin temelini oluşturan yapılaştırma kavramının toplumsal pratikler üzerine yoğunlaşması nedeniyle ontolojik derinlikten yoksun olmakla eleştirilmektedir. Yapılan eleştiriler özellikle onun kuramsal sentezlerinin toplumsal dünyadaki sosyolojik yapılara ulaşmadığı ve toplumsal dünyanın karmaşıklığ ile uyuşmadığı noktasında yoğunlaşmaktadır

Diğer yandan somut toplum çözümlemesinin sistem (veya yapı) ile yaşam dünyası arasındaki karşıtlı̆̆ın ortadan kaldırılmasıyla aşılabileceğini kabul eden Habermas sistem içindeki amaşal ve rasyonel eylem ile yaşam dünyasındaki iletişimsel eylem kategorilerini uzlaştırmaya çalışmaktadır. Modern dünyada sistem dünyasının yaşam dünyasına egemen olmasını ciddi bir sorun olarak gören Habermas "yapı" ile "aktör" arasındaki ikiliğini aşlabilmesini sistem dünyasındaki nesnel nitelikli amaçsal ve rasyonel eylemlerin yaşam dünyasındaki öznel nitelikli iletişimsel eylemlere egemen olmasının önlenmesinde görmektedir.

Toplumsal yapının iletişimsel bilgi formu olmaksızın elverişli olmadığını vurgulayan Habermas dil ve kültüre dayalı bilginin stratejik eylemlerin önkoşulu olduğunu kabul etmektedir. Frankfurt Okulu'ndan Marxizm'e uzanan bir çizgi izleyen Habermas'in modernizmi insan hayatının temelini oluşturan normları ihmal etmek ve bireyi öncellemekle eleştirmesi onu Weber'in hermeneutik sosyolojiye yaklaştırmaktadır. 
Akelsal sę̧im teorisi ile aktörlerin eylemleri üzerine çözümlemeler yapan Coleman aktörlerin karşılıklı iletişiminin önemini vurgulamaktadır. Onun bu yaklaşımı Weber'in mikro-makro kategoriler arasındaki ilişkisi teziyle çelişmekte, fakat Habermas'in aracsal/stratejik rasyonellik teorisiyle örtüşmektedir. Kullandığ1 yöntemler açısından bireyci bir sosyolog olan Coleman'ın norm ve değerlerden bağımsız olan rasyonel aktörler teorisi, sosyal düzenin açıklanmasında yetersiz bulunmakta ve mikro-makro düalizmine ilişkin örneği de ikna edici görülmemektedir ${ }^{115}$

Farklı akademik ve ulusal gelenekleri temsil eden bu sosyal bilimcilerin hemen hepsi değişik paradigmal kategorilerle eylemcilik ve işlevselcilik arasındaki kuramsal tezatları gidererek bütüncül ve sentezci bir paradigma geliştirmektedirler. 1980'li yllardan itibaren sosyal bilimlerde giderek etkisini artıran post-modern ve post-yapısalc eğilimlerin işlevselci ve eylemci teorilere karşı olan menfi tutumları bu bütüncül yaklaşımların ortaya çıkmasında belirleyici olmaktadır. Bu sonucun ortaya çımasında Klasik sosyolojide geliştirilen "pozitivist" ve "fenomonolojik" teorilerin günümüzün post-modern veya postyapısal terimleriyle ifade edilen toplumlarındaki değişim süreçlerinin analizinde yetersiz kalmış olmasının da etkin bir rol oynadığını söylemek mümkündür.

115 Andersen, a.g.e, 1991: 25-26). 


\section{KAYNAKÇA}

Adams, Bert N. and R. A. Sydie, Contemporary Sociological Theory, Pine Forge Press, Thousand Oaks, 2002.

Andersen, Heine, "Individualisme og kollektivisme samfundsvidenskabelige traditioner", Grus, Alborg 1991 bind 35, s. 7-29.

Bourdieu, Pierre, Pratike Nedenler. çev. H. Tufan, Kesit Yayınlanı, İstanbul 2006.

Bourdieu, Pierre Toplumbilim Sorunlar. (çev. Işık Ergüden), Kesit Yayıncllık, İstanbul 1997.

Bourdieu, Pierre, Distinksjonen: En sosiologisk kritikk av drömmekraften, (Oversatt, Annick Prieur), Pax, Oslo 1995.

Bourdieu, Pierre and Wacquant, Loic J. An Invitation to Reflexive Sociology, Chambridge 1992.

Bourdieu, Pierre, "The forms of Capital", Handbook of Theory and Research for the Sociology of Education. (Ed. J.G. Richardson), Westport 1986.

Bourdieu, Pierre, Distinction. A Social Critique of the Judgement of Taste. Cambridge, 1984.

Bourdieu, Pierre, "Structuralism and Theory of Sociological Knowledge", Social Research: An International Quarterly, 1968, cilt, 35 say1 4, s. 681:706.

Brante, Thomas og Andersen Heine, Leksikon i Sociologi, Akademisk Forlag Kopenhag 2007.

Broady, Donald, Sociologi og Epistemologi - om Pierre Bourdieus Författerskab och den bistoriska Epistemologin, HLS Förlag, Stokholm 1990.

Brubaker, Rogers, "Social Theory as Habitus". Bourdieu: Critical Perspectives. (Ed. Calhoun Craig, Edward Li Puma and Moishe Postone), Polity Press, Cambridge 1993. s. 212-234.

Callewaert, Staf, Kultur, peadagogisk og videnskab. Om Pierre Bourdieus habitusbegreb og praktikteori, Akademisk Forlag, Kopenhag 1992.

Coleman, James S., Foundations of Social Theory. Harvard University Press, Cambridge 1990.

Coleman, James S., "Microfoundation and Macrosocial Behaviour", The MicroMacro Link (Ed. J.C. Alexander), University of California Press, Berkeley 1987, s. 153-173. 
Coleman, James S., "Social Theory, Social Research, and a Theory of Action", American Joumal of Sociology, The University of Chicago Press, 1986 vol. 91, nr.6. 1309-1335.

Danielsen, Arild og Marianne Nordli Hansen, "Magt i Pierre Bourdieus sosiologi", i Om magt: Teori og kritikk, redieret av Fredrik Engelstad, Gyldendal, 1999 Oslo, 43-78.

Dawe, Alan, "The Two Sociologies", British Journal of Sociology, , Free Press, London 1970, vol 21: 2, s. 207-218.

Demir, Ömer ve Acar, Mustafa, Sosyal Bilimler Sözlü̈̆̈̈, Vadi Yayınları, Ankara 1997.

Fibiger, Marianne Qvortrup og Smiht, Gina Gertrud, Gads Religionsleksikon, Gads Forlag, Kopenhag 1999.

Furseth, Inger og Repstad, Pal, Innföring $i$ Religionssociologi, Universitetsforlaget, Oslo, 2003.

Giddens, Anthony, Modernitets konsekvenser, (oversatt av Are Erikson), Pax Forlag, Oslo 1997.

Giddens, Anthony, Modernitet og Selvidentitet: Selvet og Samfundet undersenmondernitet, (Oversatt av Sören Schultz Jörgensen), Hans Reitzel, Kopenhag 1996.

Giddens, Anthony,. "A Reply to My Critics", Social Theory of Modern Societies: Anthony Giddens and His Critics, (Ed. D. Held and J.B. Thompson). University Press, Cambridge 1989, s 249-301.

Giddens, Anthony, Capitalism and Modern Social Theory, Cambridge University Press, Cambridge 1985.

Giddens, Anthony, The Constitution of Society: Outline of the Theory of Structuration, University of California, Berkeley 1984.

Giddens, Anthony, A Contemporary Critique of Historical Materialism, London, Macmillan 1981.

Giddens, Anthony, New Rules of Sociological Method: A Positive Critique of Interpretive Sociologies, Hutchinson, London 1976.

http://www.denstoredanske.dk/E.T. 01.02.2015.

Habermas, Jürgen, Religion and Rationality. Essays on Reason, God, and Modernity, (Ed. Eduardo Mendieta), Polity Press, Camgridge 2002.

Habermas, Jürgen, The Theory of Communicative Action, Lifeworld and Syste, A Critique of Functionalist Reason, Beacon Press, vol. II, Boston 1987. 
Habermas, Jürgen, The Theory of Communicative Action, Reason and the Rationalization of Society, Beacon Press, vol. I, Boston 1984.

Habermas, Jürgen. Theorie des kommunikativen Handelns, Main, Frankfurt 1981.

Habermas, Jürgen, Communication and the Evulution of Society, (Transl. Thomas McCarthy and Heinemann), Education Books, London 1976.

Hansen, Peter Nörbaek og Qvist, Palle, Sumfundslex, Gyldendal, Aalborg 2009.

Jarvinen, Margaretha, "Pierre Bourdieu", Klassisk og Moderne Samfundteori, Klassisk og Moderne Samfundsteori (Ed. Heinne Andersen og Lars Bo Kaspersen), Hans Reitzels Forlag, Kopenhag 2011, s.350-371.

Espen, Jerlang. Et Tekstudvalg, Sociologiske taenkere, Hans Reitzels Forlag, Kopenhag, 2009.

Kaspersen, Lars Bo, “Anthony Giddens”, En Intruduktion til en samfundsteoritiker, Hans Reitzels Forlag, Kopenhag 2001.

Kaspersen, Lars Bo ve Blok, Anders, “Teorisynteser og Nybrud i Moderne Sociologi, Sociologi”, En grundbog til fag, Hans Reitzel Forlag, Kopenhag 2011, s.69-91.

Kirman, Ali, Din Sosyolojisi Terimler Sözlüğ̈̈, 2. Bask1 Rağbet Yayınları, İstanbul 2011.

Larsen, Steen Nepper og Pedersen, Inge Kryger, Sociologisk Leksikon, Hans Reitzels Forlag. Kopenhag 2011.

Marshall, Gordon, Sosyoloji Sözlüğ̈̈, çev. Osman Akınbay ve Derya Kömürcü, Bilim ve Sanat Yayınları, Ankara 1999.

Österberg, Dag, Sociologiske nöglebegreber og deres oprindelse, (Oversat. af Manni Crone), Akademisk Forlag, Kopenhag 2005.

Parsons Talcott, The Structure of Social Action, The Free Press, New York: 1937.

Panofsky, Erwin, Gothic Architecture and Scholasticism, New American Library, New York 1976.

Ritzer, George, Modern Sosyoloji Kuramlar, (çev. Himmet Hülür), De Ki Yayım Ltd Ști, Ankara 2011.

Thomsen, F. Jens Peter, "Diskursanalyse", Klassiske og Moderne Samfundsteori (Ed. Heine Andersen og Lars Bo Kaspersen), Hans Reitzels Forlag, Kopenhag 2011.

Wallace, Ruth A. ve Wolf, Alison, Căgdass Sosyoloji Kuramlar, çev. Leyla Elburuz ve M. Rami Ayas, Punto Yayınc1lık, İzmir 2004. 
Wacquant J.D Loïc ve Bourdieu Pierre, Refleksiv sociologi, Hans Reitzels Forlag, Kopenhag 1996.

Weber, Max. Wirtshaft und Gesellschaft, J.C. B. Mohr, Verlag Von, Tübingen1922.

Willis, Paul, Learning to Labour. How Working Class Kids Get Working Class Jobs, Saxon House, Farnborough 1977. 